\title{
The influence of chromium ions on the growth of the calcium hydroxyapatite crystal
}

\author{
Samira M. Sallam ${ }^{1 *}$, Khairi M. Tohami ${ }^{2}$, Abdelsattar M. Sallam ${ }^{3}$, Lotfi I. Abo Salem ${ }^{1}$, \\ Faten Adel Mohamed ${ }^{1}$ \\ ${ }^{1}$ Department of Physics, Science College, Benha University, Benha, Egypt; ${ }^{*}$ Corresponding Author: drsmsallam@yahoo.com \\ ${ }^{2}$ Department of BioPhysics, Science College, Cairo, Egypt \\ ${ }^{3}$ Department of BioPhysics, Science College, Ain Shams University, Cairo, Egypt
}

Received 21 June 2012; revised 15 August 2012; accepted 28 August 2012

\begin{abstract}
Hydroxyapatite $\left(\mathrm{Ca}_{10}\left(\mathrm{PO}_{4}\right)_{6}(\mathrm{OH})_{2}\right)$ is widely used as bio-ceramic materials and as adsorbents for separation of bio-molecules. These materials have also been used as adsorbents for heavy metals, supports and as catalysts in oxidation and dehydrogenation reactions. The catalytic performance of these materials depend on the lattice substitution of $\mathrm{Ca}$ sites in Hydroxyapatite structure by varied cations as $\mathrm{Na}, \mathrm{Mg}, \mathrm{Sr}$ and $\mathrm{Mn}$, which result in changes in various structural pro perties as crystallinity and morphology. Pure calcium hydroxyapatite (S1) and $\mathrm{Cr}$ loaded hydroxyl apatite (S2, S3, S4 and S5) of different chromium concentrations have been prepared by wet precipitated method. An in-vitro examination is essential to investigate the mechanism of the deficient $\mathrm{HA}$ and tissue interface reaction by preparing SBF (Simulated Body Fluid) through the elemental and chemical analysis of $\mathrm{Ca}, \mathrm{P}$ and $\mathrm{Cr}$. FTIR used to analyze the samples after incubation in SBF for 24 day. PH of the samples also was measured at the first period of immersion time. At high loading of chromium ions, the formation of carbonate apatite decrease. The concentrations of the chromium in the $\mathrm{Cr}$ HA crystal during the soaking in SBF are very safe dose for human.
\end{abstract}

Keywords: Hydroxyapatite Crystal; Calcium Growth; Crystallinity; Bioceramics

\section{INTRODUCTION}

Hydroxyapatite (HAp), chemical formula $\mathrm{Ca}_{5}\left(\mathrm{PO}_{4}\right)_{3} \mathrm{OH}$, is considered the structural template for the mineral phase of bone, dentin and enamel. Synthetic HAp is widely used in medicine and dentistry because of its biocom- patibility and bioactivity properties. Biological HAp have multiple substitutions and deficiencies at all ionic sites. The close relationship between substitutions and bioactivity of synthetic substituted HAp has been demonstrated by in vitro and in vivo studies [1].

Chromium-loaded hydroxyapatite catalysts $\mathrm{Cr}(\mathrm{x}) / \mathrm{CaHAp}$ $\left(0.1 \mathrm{x}_{-} 3.7\right.$ wt.\% $\left.\mathrm{Cr}\right)$ was prepared by ion exchange and characterized by several techniques including FTIR, Raman, XPS, UV-vis-NIR spectroscopies. After calcination in air, several isolated chromium species were identified the surface $\mathrm{Cr}^{3+}$ ions in distorted octahedral symmetry, bulk octahedral $\mathrm{Cr}^{3+}$ ions, octahedral $\mathrm{Cr}^{5+}$ ions in low concentration and $\mathrm{Cr}^{6+}$ ions. The $\mathrm{Cr}^{6+}$ ions present as monochromates are predominant only at very low loadings $\left(\mathrm{x}_{-} 0.1 \mathrm{wt} . \% \mathrm{Cr}\right)$ whereas, at higher Chromium amounts (up to $3.7 \mathrm{wt} \% \mathrm{Cr}$ ), $\mathrm{Cr}^{3+}$ species are preponderant The majority of $\mathrm{Cr}^{3+}$ ions are located on the apatite surface; they do not form $\mathrm{Cr}_{2} \mathrm{O}_{3}$ crystallites but isolated $\mathrm{Cr}^{3+}-\mathrm{O}-\mathrm{Ca}^{2+}$ or $\mathrm{Cr}^{3+}-\mathrm{O}-\mathrm{Cr}^{3+}$ entities at the highest $\mathrm{Cr}$ amounts. The $\mathrm{Cr}(\mathrm{x}) / \mathrm{CaHAp}$ catalysts were tested in propane oxidative dehydrogenation in the $300-5508^{\circ} \mathrm{C}$. temperature range. The $\mathrm{Cr}^{6+}$ centre initially present on the catalysts may initiate the cracking of propane because of their acidity and improve the conversion; however, as they are reduced by the reaction mixture, the propane conversion decreases upon running at $5508^{\circ} \mathrm{C}$. $\mathrm{Cr}^{2+}$ ions are also formed upon running. Isolated $\mathrm{Cr}^{3+}$ species are believed to be responsible for the propylene formation (propylene yield around $7 \%$ at $5508^{\circ} \mathrm{C}$ ).

This limitation of performance is ascribed to the decrease of the basicity induced by the fixation of $\mathrm{Cr}^{3+}$ which counter balances the positive effect of chromium on oxygen reactivity. The proposed mechanism involves the contribution of oxygen vacancies or $\mathrm{Cr}^{2+}$ species [2].

Collidal $\mathrm{Ca}_{10}\left(\mathrm{PO}_{4}\right)_{5}(\mathrm{OH})_{2}$ (HA) particles doped with $\mathrm{Cr}^{3+}$ ions in different mole ratios $\left[\mathrm{Cr} /(\mathrm{Ca}+\mathrm{Cr})=\mathrm{X}_{\mathrm{cr}}\right]$ by a coprecipitation method were characterized by different techniques. The particle size increased with an increase in $\mathrm{X}_{\mathrm{cr}}$. When doped at $\mathrm{X}_{\mathrm{cr}} \geq 0.13$ irregular particles were 
formed besides long rectangular particles containing $\mathrm{Cr}^{3+}$ ions less than ca 0.03 in $X_{c r}$. The compositions of these two kinds of particles showed that the long rectangular particles were HA and the irregular particles were hydrated calcium chromium phosphate hydroxide. The growth of HA apatite crystals was strongly promoted by doping $\mathrm{Cr}^{3+}$ ions [3].

Many researches were given on the association between chromium and diabetes, as it is an essential mineral for human health [4]. Chromium play an important role as it is may reduce blood sugar levels.

It improves the ability of insulin to convert glucose into energy to the cells of the body $[5,6]$. Chromium is an antioxidant, which helps protect the body against free radical damage (oxidation).

The present work aimed to investigate a dial function through, firstly, the role of Deficient Hydroxy apatite in orthopedics, plastic and dental surgery. Secondly, HA acts as a carrier for chromium ions which play an important role in improving the performance of the Langerhans cells in the pancreas $[7,8]$.

\section{MATERIALS AND METHODS}

A wet method was adopted for the preparation of HA and calcium deficient HA .Some samples were prepared by wet precipitated method. One of these samples is pure calcium phosphate bioceramic (S1) and the other samples are calcium phosphate bioceramic doped by chromium nitrate of different concentrations ( $\mathrm{S} 2, \mathrm{~S} 3, \mathrm{~S} 4$ and S5) of $\left[0.005,0.01,0.02\right.$ and 0.03 mole] of $\mathrm{Cr}\left(\mathrm{NO}_{3}\right)_{2} \cdot 9 \mathrm{H}_{2} \mathrm{O}$ respectively.

\section{Preparation of Calcium Deficient HA Sample}

Calcium phosphate bioceramic powder was prepared by an aqueous precipitation technique using 0.16 Mole of calcium nitrate titrahydrate $\left[\mathrm{Ca}\left(\mathrm{No}_{3}\right)_{2} \cdot 4 \mathrm{H}_{2} \mathrm{O}\right]$ as a source of calcium which dissolving in one liter of de-ionized water and 0.096 Mole of di-ammonium hydrogen orthophosphate $\left[\left(\mathrm{NH}_{4}\right)_{2} \mathrm{HPO}_{4}\right]$ as a source of phosphorous which dissolving in one liter of de-ionized water. In order to prepare HA doped by $\mathrm{Cr}$ ions, different amounts of chromium nitrate $\mathrm{Cr}\left(\mathrm{No}_{3}\right)_{2} \cdot 9 \mathrm{H}_{2} \mathrm{O}[0.005,0.01,0.02,0.03$ mole] dissolved in one liter of de-ionized water with 0.16 Mole of calcium nitrate titrahydrate $\left[\mathrm{Ca}\left(\mathrm{No}_{3}\right)_{2} \cdot 4 \mathrm{H}_{2} \mathrm{O}\right]$. The $\mathrm{pH}$ of both solutions was adjusted to about 10 by the addition of a dilute $\mathrm{NH}_{4} \mathrm{OH}$ solution proper strength. Following $\mathrm{pH}$ adjustment, 0.096 Mole $\left[\left(\mathrm{NH}_{4}\right)_{2} \mathrm{HPO}_{4}\right]$ solution was fed from a burette, in a dropwise manner (2 - 5 $\mathrm{ml} / \mathrm{min}$ ), into a stirred solution of $0.16 \mathrm{M}\left[\mathrm{Ca}\left(\mathrm{No}_{3}\right)_{2} \cdot 4 \mathrm{H}_{2} \mathrm{O}\right]$ heated to $60^{\circ} \mathrm{C}$ on a hot plate, during this reaction $\mathrm{PH}$ must maintain constant at 10 by the addition of a dilute $\mathrm{NH}_{4} \mathrm{OH}$ solution or $\mathrm{HNO}_{3}$. After mixing, the solution was aged and vigorously stirred at its boiling point for about $2 \mathrm{~h}$ in a sealed container. The HA precipitates were recovered from the solution by sucking filtration and washed three times with de-ionized water, followed by drying at $100^{\circ} \mathrm{C}$ overnight. The powder was dis-agglomerated by gently grinding.

\section{CHARACTERIZATION}

A simulated body fluid (SBF) is a model solution simulating the inorganic part of the blood plasma.

The SBF was prepared according to Kokubo T. (2006) [9], to investigate the effects of the $\mathrm{Cr}$ ions on the mineralization process. Its ion concentrations almost equal to those of human plasma. The following powder reagent grade chemicals have to be stocked in a desiccator.

De-ionized water is used for the preparation of SBF: sodium chloride $(\mathrm{NaCl})$, sodium hydrogen carbonate $\left(\mathrm{NaHCO}_{3}\right)$, Potassium chloride $(\mathrm{KCl})$, di-potassium hydrogen phosphate trihydrate $\left(\mathrm{K}_{2} \mathrm{HPO}_{4} \cdot 3 \mathrm{H}_{2} \mathrm{O}\right)$, Magnesium chloride hexahydrate $\left(\mathrm{MgCl}_{2} \cdot 6 \mathrm{H}_{2} \mathrm{O}\right)$, Calcium chloride $\left(\mathrm{CaCl}_{2}\right)$, sodium sulfate $\left(\mathrm{Na}_{2} \mathrm{SO}_{4}\right)$, Tris-hydroxymethyl aminomethane:

$\left(\left(\mathrm{HOCH}_{2}\right)_{3} \mathrm{CNH}_{2}\right)$ (Tris), $1 \mathrm{M}(\mathrm{mol} / \mathrm{l})$ and Hydrochloric Acid, 1M-HCl. PH electrode was used to measure the changing in the $\mathrm{PH}$ value of the solution during the immersion of the samples in SBF.

\section{RESULTS AND DISCUSSION}

The elemental analysis of the phosphorus and calcium ions after immersion of the samples in SBF (simulated body fluid) for 24 day at temp. $37^{\circ} \mathrm{C}$, showed that, when the samples incubated in SBF, there were significant differences between the samples and the controls for chemical analysis. The calcium and phosphorus ions concentration of fresh SBF which prepared in this study is about $95.7 \mathrm{ppm}$ and $34.3 \mathrm{ppm}$ of calcium and phosphorous ions, respectively. There was a lower amount of $\mathrm{Ca}$ and $\mathrm{P}$ in the samples doped by $\mathrm{Cr}$ ions than in controls as shown in Figure 1. After immersion of the calcium phosphate bioceramic samples in simulated body fluid (SBF) solution, the concentration of $\mathrm{Ca}$ and $\mathrm{P}$ ions were sound to be changed in the SBF solution. Hence, it is obvious that an interaction between the SBF and the samples has occurred. During the immersion time, it was observed that the concentrations of $\mathrm{Ca}$ and $\mathrm{P}$ decreased in the solution and this is may be due to the migration of $\mathrm{Ca}$ and $\mathrm{P}$ from the solution to the sample to form the carbonate like apatite layer in the samples.

From the chemical analysis for the chromium ions in the $\mathrm{Cr}$ _HA samples (S2, S3, S4 and S5) after immersion for (24 day) in SBF. It was observed in Table 1 that, the concentrations of $\mathrm{Cr}^{3+}$ ions doped in $\mathrm{HA}$ and released after implantation is in a safety range for all samples 

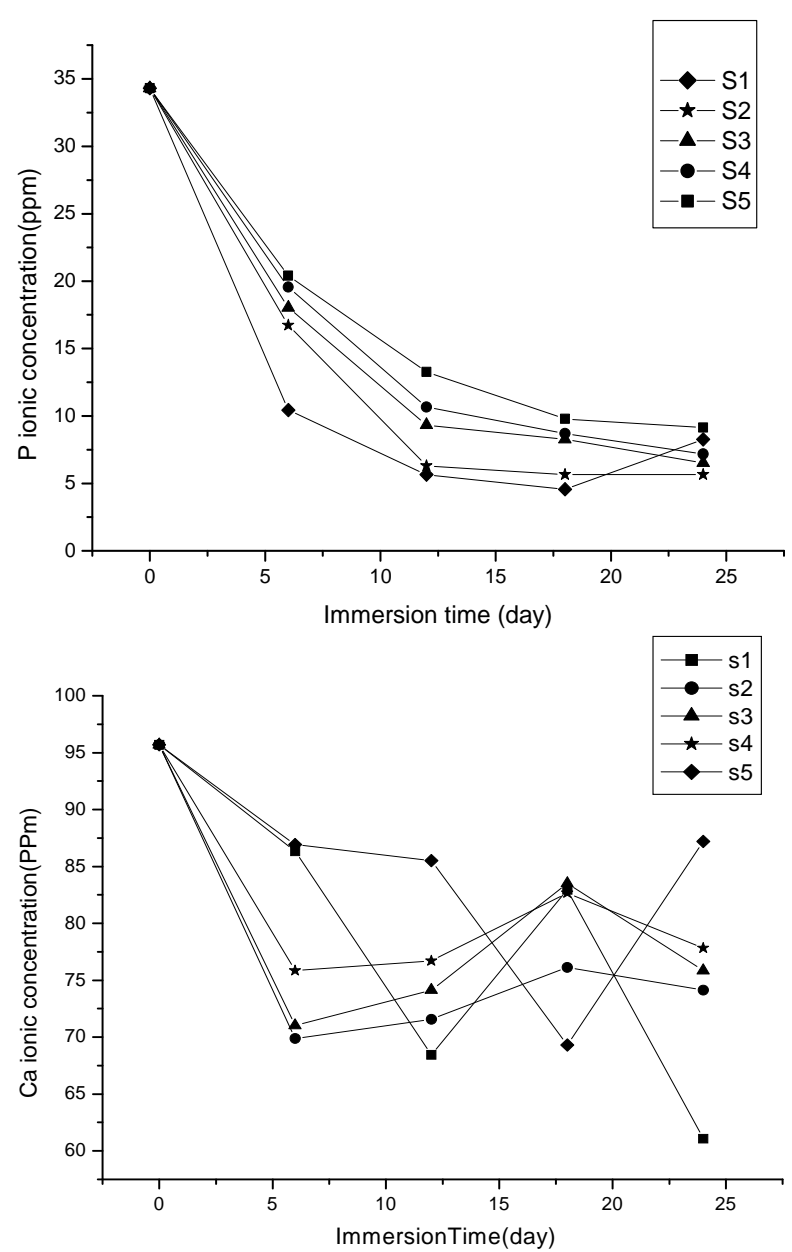

Figure 1. Calcium and phosphorus ion concentration of SBF for the prepared HA (S1) and and HA doped by chromium ions (S2, S3, S4 and S5) of concentrations [0.005, 0.01, 0.02 and 0.03 mole] of $\mathrm{Cr}\left(\mathrm{NO}_{3}\right)_{2} \cdot 9 \mathrm{H}_{2} \mathrm{O}$ respectively at various time of immersion.

Table 1. The rate of dissolution of $\mathrm{Cr}^{3+}$ ions in $\mathrm{Cr}$ loaded hydroxyl apatite samples (S2, S3, S4 and S5) of concentrations $\left[0.005,0.01,0.02\right.$ and 0.03 mole] of $\mathrm{Cr}\left(\mathrm{NO}_{3}\right)_{2} \cdot 9 \mathrm{H}_{2} \mathrm{O}$ respectively after immersion for 24 day in SBF.

\begin{tabular}{ccccc}
\hline Samples & S2 & S3 & S4 & S5 \\
\hline concentrations of $\mathrm{Cr} \mathrm{mg} / \mathrm{L}$ & 0.45 & 0.53 & 1.11 & 1.77 \\
\hline
\end{tabular}

according to the fact that the safety dose of $\mathrm{Cr}^{3+}$ for diabetic patient is about (400 to 1000) mcg per day [6], hence the implantation will not cause any toxicity but it will help to simulate the islets of Langerhans in the pancreas to produce the insulin in order to convert the sugar from the blood into energy to the cells.

The samples were soaked in simulated body fluid (SBF) for 24 day, FTIR used to analyze the surface of the samples after the incubation period. Figure 2 shows the FTI $\mathrm{R}$ spectrum of the samples.

The two bands at 3597 and $642 \mathrm{~cm}^{-1}$ are assigned to

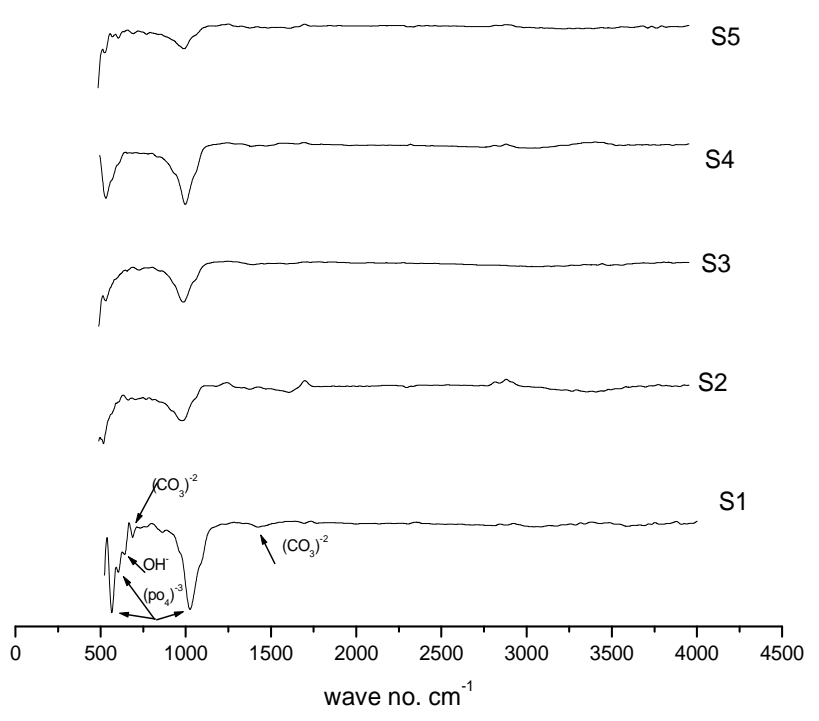

Figure 2. FTIR peaks of prepared HA (S1) and HA doped by chromium ions (S2, S3, S4 and S5) of concentrations [0.005, $0.01,0.02$ and 0.03 mole] of $\mathrm{Cr}\left(\mathrm{NO}_{3}\right) 2 \cdot 9 \mathrm{H}_{2} \mathrm{O}$ respectively after immersion for 24 day in SBF.

the stretching and bending modes of $\mathrm{OH}$ groups, respectively. The presence of $(\mathrm{PO} 4)^{-3}$ is attested by 1$)$ the P-O stretching modes appearing at $\left.1024 \mathrm{~cm}^{-1}\left(v_{3}\right) ; 2\right)$ the $\mathrm{O}-\mathrm{P}-\mathrm{O}$ bending modes observed at 603 and $566 \mathrm{~cm}^{-1}\left(\mathrm{v}_{4}\right)$ [10].

In addition to these phosphate and hydroxide bands, there are bands corresponding to carbonate groups at 1423 $\mathrm{cm}^{-1}$ for the $\left(v_{3}\right)$ bands (asymmetric stretching vibration), around $862 \mathrm{~cm}^{-1}$ for the $\left(v_{2}\right)$ bands (bending out-of plane vibration), and at 764 and $734 \mathrm{~cm}^{-1}$ for the $\left(v_{4}\right)$ band (bending in-plane vibration), which is an indication of the presence of carbonate bone-like apatite layer on the surface of the samples [11]. Upon the introduction of $\mathrm{Cr}$ in the samples, in the samples with high addition of chromium ions concentrations, the intensity of the bands corresponding to the hydroxyl groups at approximately 642 $\mathrm{cm}^{-1}$ and $3597 \mathrm{~cm}^{-1}$ reduced the same effect was observed for the bands corresponding to $\left(\mathrm{PO}_{4}\right)^{-3}$ at 1024 $\mathrm{cm}^{-1}, 603 \mathrm{~cm}^{-1}$ and $566 \mathrm{~cm}^{-1}$, also the intensity of the bands corresponding to the carbonate decrease, which indicate that the formation of the carbonate apatite decreases as the chromium ions concentrations increases in the samples. This may be due to, as $\mathrm{Cr}$ ion concentrations increases in the samples, the dissolution rate increased and precipitated on the surface of the sample inhibited the precipitation of amorphous calcium phosphate on the surface of the sample, hence the apatite layer formation decreased.

$\mathrm{PH}$ of the samples was measured at the first period of the immersion time as shown in Figure 3. In the first hours, $\mathrm{PH}$ value of the solution increased and this may be due to the increase in the dissolution of the $\mathrm{Ca}$ ions into the solution in this period, where the $\mathrm{Ca}$ is alkaline mine- 


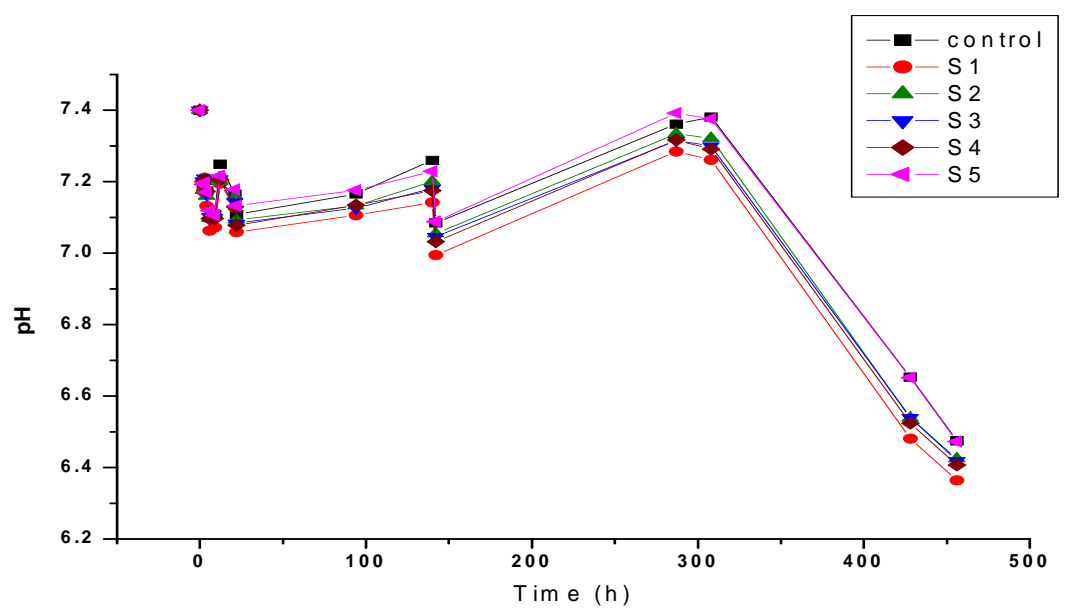

Figure 3. The variation in $\mathrm{pH}$ with time for prepared HA (S1) and Cr loaded hydroxyl apatite (S2, S3, S4 and S5) of concentrations [0.005, 0.01, 0.02 and 0.03 mole] of $\mathrm{Cr}\left(\mathrm{NO}_{3}\right) 2 \cdot 9 \mathrm{H}_{2} \mathrm{O}$ respectively at the first time of the immersion period.

ral increases the PH. Finally PH decreased, this may be due to the decomposition of some constituents of the SBF solution such as:

$$
\begin{aligned}
\mathrm{HCO}^{-3} & \leftrightarrow 2 \mathrm{CO}_{3}^{-2}+\mathrm{H}^{+} \\
\mathrm{HPO}_{4}^{2-} & \leftrightarrow 2 \mathrm{PO}_{4}^{-3}+\mathrm{H}^{+} \\
\mathrm{H}_{2} \mathrm{O} & \leftrightarrow \mathrm{OH}^{-}+\mathrm{H}^{+}
\end{aligned}
$$

The samples at which the concentration of $\mathrm{CO}_{3}^{2-}$ group increased, the $\mathrm{Ca}$ and $\mathrm{P}$ ions interact with the $\mathrm{OH}$ molecules in order to form amorphous calcium phosphate, which interact with $\mathrm{CO}_{3}^{2-}$ transformed into more stable crystalline bone-like apatite leaving the $\mathrm{H}^{+}$ion free in the solution combine with $\mathrm{OH}$ producing water molecules which in turn decrease PH.

\section{CONCLUSION}

Upon the introduction of $\mathrm{Cr}$ in the samples, the formation of the carbonate apatite layer decreases as the chromium ions concentrations increases in the samples, hence it is recommended to use the small concentrations of chromium ions while doping in the HA crystal. The concentrations of the $\mathrm{Ca}$ and $\mathrm{P}$ ions at the SBF are decreased indicating that there are CHA layer formed, as confirmed by FTIR analysis and the PH value decreased. From the chemical analysis of $\mathrm{Cr}_{-}$loaded $\mathrm{HA}$ samples after immersion in SBF for 24 day, the dissolution rate of $\mathrm{Cr}^{3+}$ are considered to be a safe dose for human.

\section{REFERENCES}

[1] Zapanta LeGeros, R. (1991) Calcium phosphates in oral biology and medicine. Karger, New York.

[2] Pang, Y.X. and Bao, X. (2003) Influence of temperature, ripening time and calcination on the morphology and cry- stallinity of hydroxyapatite nanoparticles. Journal of the European Ceramic Society, 23, 1697-1704. doi:10.1016/S0955-2219(02)00413-2

[3] Wakamura, M., Kandori, K. and Ishikawa, T. (1997) Influence of chromium (III) on the formation of calcium hydroxyapatite. Polyhedron, 16, 2047-2053. doi:10.1016/S0277-5387(96)00513-X

[4] Jeejebhoy, K.N., Chu, R.C., Marliss, E.B., Greenberg, G.R. and Bruce-Robertson, A. (1977) Chromium deficiency, glucose intolerance and neuropathy reversed by chromium supplementation in a patient receiving long-term total parenteral nutrition. American Journal of Clinical Nutrition, 30, 531-538.

[5] Anderson, R.A. (1998) Chromium, glucose intolerance and diabetes. Journal of the American College of Nutrition, 17, 548-555.

[6] Anderson, R.A. (2000) Chromium in the prevention and control of diabetes. Diabetes and Metabolism, 26, 22-27.

[7] Chang, X., Jorgensen, A.M., Bardrum, P. and Led, J.J. (1997) Solution structures of the R6 human insulin hexamer. Biochemistry, 36, 9409-9422.

[8] Benedict, C., Hallschmid, M., Hatke, A., Schultes, B., Fehm, H.L., Born, J. and Kern, W. (2004) Intranasal insulin improves memory in humans. Psychoneuroendocrinology, 29, 1326-1334. doi:10.1016/j.psyneuen.2004.04.003

[9] Kokubo, T. and Takadama, H. (2006) How useful is SBF in predicting in vivo bone bioactivity? Biomaterials, 27, 2907-2915. doi:10.1016/j.biomaterials.2006.01.017

[10] Boucetta, C., Kacimi, M., Ensuque, A., et al. (2004) Oxidative dehydrogenation of propane over chromium-loaded calcium-hydroxyapatite. Applied Catalysis A: General, 356, 201-210. doi:10.1016/j.apcata.2009.01.005

[11] Rey, C., Renugo Palakrishnan, V., Collins, B. and Glimcher, M.J. (1991) Fourier transform infrared spectroscopy study of the carbonate ions in bone mineral during aging. Calcified Tissue International, 49, 251-258. doi:10.1007/BF02556214 